\title{
LAND USE DATA IN THE MIDDLE MAULE RIVER SUB-BASIN: CLASSIFICATION AND COMPARISON BETWEEN 1999 AND 2019
}

\author{
M. N. Tapia ${ }^{1}, *$, M. V. B. Morais ${ }^{2}$ \\ ${ }^{1}$ Escuela de Ingeniería Civil, Facultad de Ciencias de la Ingeniería, Universidad Católica del Maule, Talca, Chile - \\ marcelo.tapia@alu.ucm.cl \\ ${ }^{2}$ Departamento de Obras Civiles, Facultad de Ciencias de la Ingeniería, Universidad Católica del Maule, Talca, Chile - \\ bmarcos@ucm.cl
}

KEY WORDS: Land cover use; Landsat; Drought; Human activities; Chile; Semi-automatic Classification Plugin

\begin{abstract}
:
The use of satellite images is a modern strategy for the evaluation and prediction of various weather scenarios. In addition, this is a key tool for the development of environmental sciences. Since the end of the last decade, Chile has been suffering from a megadrought associated with climate change. In this context, this study proposes to evaluate the role of land use change in the Middle Maule River sub-basin, located in the Maule Region, Chile. This is an important sector characterized by a significant agricultural and hydroelectric contribution. To do so, this study performs a supervised classification of land cover through the usage of QGIS software and Landsat images for the years 1999 and 2019. The results show the growth of areas without vegetation due to a great drought facing the Central Zone of the country. Additionally, there is a decrease in available bodies of water. This article leaves open future research on the impact of the main economic activities of the region.
\end{abstract}

\section{INTRODUCTION}

\subsection{General Instructions}

Human activities change the land cover and use, since it alters the natural surfaces and thermal (Kalnay and Cai, 2003), radiative (Morais et al., 2018), and physical properties (Huntra and Keener, 2017), influencing in the atmosphere (Pielke et al., 2011). Besides, anthropogenic and natural changes in the soil involve several environmental problems such as the impact on biodiversity through degradation or destruction of habitats, it also degrades the soil, pollutes water bodies as a result of the removal of forests (Newbold et al., 2015). It also produces changes in atmospheric temperature due to the emission of greenhouse gases. From another perspective, it also generates alterations to the hydrological cycle (Legesse et al., 2003; Li et al., 2007; Rudke et al., 2019). The change in land use through the monoculture of exotic species is contributing both to the loss of habitat and biodiversity and the species extinction (Fierro et al., 2016). The monitoring of biodiversity and the environmental impact resulting from human activities is essential since it helps to design mitigation and adaptation activities to prevent higher losses of biological diversity. At this point, the evaluation of space-time changes in ecosystems is critical (Pettorelli et al., 2014).

In recent years, remote sensing has become an essential tool in understanding the role of Land Use and Land Cover (LULC) change in the climate of a region, especially with the aid of numerical modeling of the atmosphere (Fan et al., 2014; Morais et al., 2017; Solecki and Oliveri, 2004). In addition, the use of satellite imagery has become fundamental in urban planning, agriculture, energy, among other activities (Csiszár et al., 2019; Ho et al., 2001; Kar and Liou, 2019; Li et al., 2019; Wilson et al., 2019; Xiao et al., 2006). In recent times, research on LULC mapping has increased considerably with $87.9 \%$ of publications in the 21st century ( $\mathrm{Yu}$ et al., 2014). In this sense, various satellite products have emerged in recent years for the entire globe, which increases the available mappings (Grekousis et al., 2015). Several authors have studied and compared different global mapping products on land use and have concluded that they have discrepancies in terms of results and databases, consequently, several products have been developed at regional level (Capucim et al., 2015; Congalton et al., 2014; Congalton, 1991; Herold et al., 2008; Rudke et al., 2019).

In South America, the study of LULC is quite diverse. Hansen et al., (2013), for example, shows that, between 2000 and 2012 , South America suffered deforestation of approximately 542,000 $\mathrm{km}^{2}$. In Chile, many studies for multiple application has been done. Echeverria et al., (2006), showed the deforestation of $67 \%$ of Chilean temperate forests between 1975 and 2000 for the south-central region. For the same region, Nahuelhual et al. (2012) showed that this deforestation is related to plantation expansion. Zhao et al. (2016) produced a multi-seasonal and dynamic series of LULC maps using Landsat 8 imagery for 2013 and 2014. Using LULC, Rojas et al., (2019) quantified the urban growth over the wetland for the metropolitan area of Concepción, in south Chile. Building scenarios of LULC, Manuschevich et al., (2019), discuss the forest policy, transitions and environmental outcomes linking political and economic processes. Curtis et al. (2019) show that southern Chile is the region with the most suitable condition for the presence of non-native pine plantations. Liu et al. (2019) studied the environmental impact of lithium mining in the Atacama Salt Flat using Landsat imagery and MODIS land products. Martínez Martínez et al., (2019) studies the effect on the effects of the land use changes on the net primary product for south-central Chile from 2000 to 2014.

Despite the various LULC studies for Chile, there is a gap in understanding their changes and the impact on the hydrological

\footnotetext{
* Corresponding author
} 
cycle and climate, just as the country is experiencing a megadrought that began a decade ago (Garreaud et al., 2019). In this context, this study aims to analyze the changes in LULC in the Middle Maule River sub-basin, which is important for the power generation and water supply of the Maule region in south-central Chile, between the years 1999 and 2019.

\section{DATA AND METHODOLOGY}

\subsection{Characteristics of the study region}

The Maule River Basin is located in the Central Zone of Chile (Figure 1), has an area of 20,300 $\mathrm{km}^{2}$, and has an average flow of $467 \mathrm{~m}^{3} / \mathrm{s}$ (BCN, 2017). The basin has an installed hydroelectric power of 1,368 MW, approximately $9 \%$ of national production(Generadoras de Chile, 2017). In the Maule Region, there are $17.2 \%$ of the national silvoagropecuary production with activities such as forest plantations, cereals, fruit trees, viticulture, among others. On the other hand, in the region, there is $18 \%$ of the total national livestock (ODEPA, 2018).

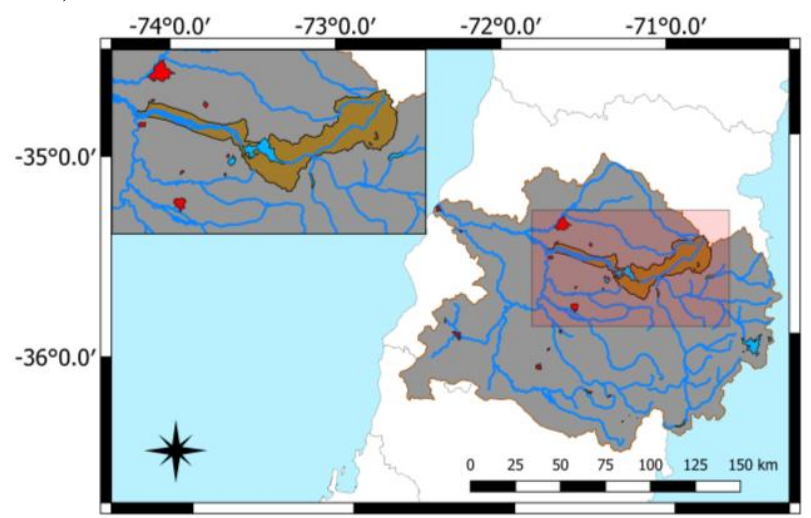

Figure 1: Localization of the Maule River Basin within the Middle Maule sub-basin. Red areas are cities.

The Maule River Basin is composed of 9 sub-basins. This study focuses on the Middle Maule sub-basin (top left map in Figure 1), which has a surface area of $943 \mathrm{~km}^{2}$ (MOP-DGA, 2003). According to the land and vegetation use cadaster carried out by the Chilean Geospatial Data Infrastructure (IDE, 2017), it can be found for the year 2016, that the land use was mainly classified in 3 groups: vegetation, agricultural land, and forests. The rest corresponds to bodies of water, and meadows and thickets. This sub-basin has a high hydroelectric activity with at least four power stations in Maitenes, Carretones, Bajo Lircay, which correspond to passing plants, and in Colbún, it can be found a reservoir plant (MOP-DGA, 2008).

Inside the sub-basin area does not contain any city or town, but in its vicinity, it can be found Talca, San Clemente, Maule, Colbún, and San Javier. The water bodies that stand out in this sub-basin are Maule, Claro, and Blanquillo rivers, in addition to having two lagoons: La Turbia and Laguna del Caracol. Also, it contains a large amount of Colbún Lake, an artificial reservoir. Many estuaries and streams are also found, in which stand out Loss Tricahues, Los Teatinos and Armerillo estuaries, and the Los Boldos, La Laguna, and El Burro streams.

\subsection{Satellite Imagery}

Considering the long period range for this study, the Landsat scenes were used. The images are freely available on the website of the United States Geological Survey (USGS). The database corresponds to an image of Landsat 4-5, for the year 1999, and an image of Landsat 8 for the year 2019. Both scenes were selected considered cloudiness conditions, which were the months of October to December for 1999 and 2019, respectively. Both scenes have a spatial resolution of $30 \mathrm{~m}$, and the data are available in $185 \mathrm{~km} \mathrm{x} 180 \mathrm{~km}$, defined in a Worldwide Reference System (WRS-2; Loveland and Irons, 2016). For the classification, the Bands Blue, Green, and Red were used, corresponding to the bands 1, 2, and 3 for Landsat 45 TM (1999 image), and the bands 2, 3, and 4 for the Landsat 8 OLI (2019 image).

\subsection{Classification}

In the preprocessing stage, both images used the Dark-ObjectSubtraction-1 (DOS1) atmospheric correction algorithm to improve the estimation of land surface reflectance (GomezDans, 2020). The supervised classification method was used to classify the land cover. For the training set, the classification carried out by the IDE (2017) was used, that is, the categories of land use are Bare soil, Agricultural land, Forests, Meadows and Thickets (MaT), Water and Snow. Image processing was performed on the free QGIS 3.8.2 software developed by the OSGeo foundation, using the Semi-Automatic Classification Plugin (SCP; Leroux et al., 2018). For each class, 50 samples were collected using high-resolution imaging (Google Earth), following Rudke et al. (2019). Figure 2 presents the flowchart of the classification process:

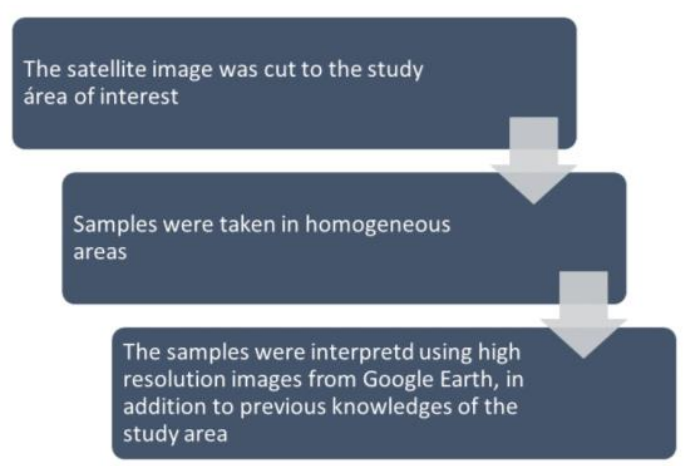

Figure 2: Flowchart of the Landsat satellite image classification process for both the years 1999 and 2019.

For each image (1999 and 2019), at least 300 scattered samples were taken. The classification algorithm used was Spectral Angle Mapping (SAM; Kruse et al., 1993). This method considers that the image data was converted to surface reflectance, determining the spectral similarity by the angle formed between two spectra (Markoski and Rolim, 2012). After classification, an ASCII point-by-point file was generated and subsequently converted to a comma-delimited values (csv) file. The csv file with the soil classification was compared and worked on the free Octave programming software, that uses the $M$ language. In this software, it was calculated both the number of specific changes per class and the amount of soil that remained in its category. The results were analyzed comparing the percentage difference and maintenance between both years for each pixel.

\section{RESULTS AND DISCUSSION}

Figure 3 shows the results obtained by the supervised classification. Figure 4 presents the LULC percentage for each 
year and the changes between 1999 and 2019. Regarding the classification and comparison of land cover it is evident that the main land occupation for 1999 corresponds to agriculture (33.8\%) followed by forests with (20.7\%), while for 2019 the highest use of soil corresponds to areas without vegetation (30.4\%) followed by agriculture and forests $(23.6 \%$ and $23.1 \%$ respectively).

Besides, it can be seen that the bodies of water decreased by 7\%. On the other hand, agricultural activities have also decreased by $10.2 \%$. Regarding meadows and thickets, the amount of soil has remained almost constant with a decrease of $0.3 \%$. The amount of snow present has decreased by $2.1 \%$. The land classified as forest has presented an increase of $2.4 \%$. Finally, it was found a high growth of areas without vegetation, with an increase of $16.3 \%$. This increase in bare soil contributes to the high levels of temperature in the region (Alvenäs and Jansson, 1997). This result relates to the land degradation process found in other studies for Chile (Aronson et al., 1998; Nahuelhual et al., 2012; Pereira, 2019; Schulz et al., 2010).

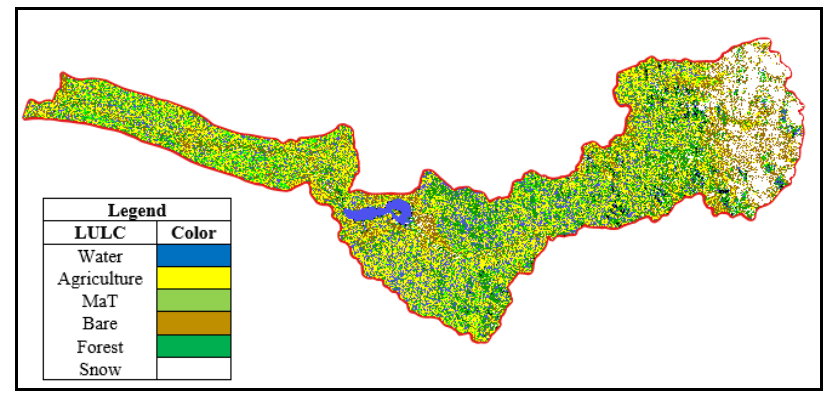

(a)

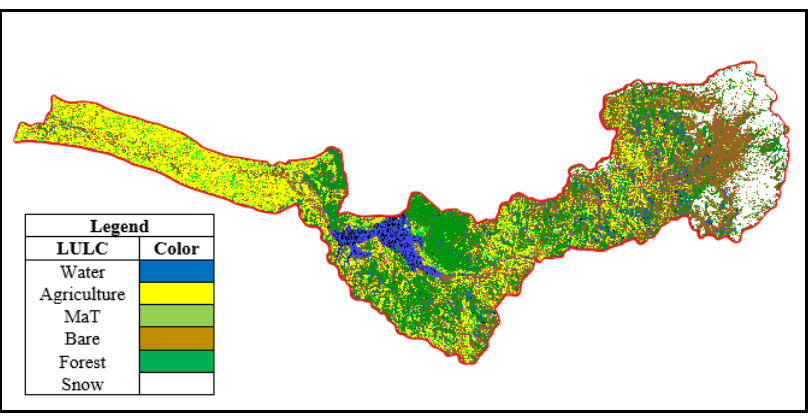

(b)

Figure 3. Results of supervised classification SAM for (a) 1999 and (b) 2019.

For the specific change of soil (Table 1), several significant changes in LULC can be observed. The same result can also be seen in the Sankey diagram, shown in Figure 5. This shows the changes in land cover, where the width of the arrow indicates the magnitude of the specific change. In the left column are the corresponding classification data for 1999, while in the right column are the classification data for 2019.

The bodies of water had a considerable change, with $32 \%$ of the change in 1999 to forest in 2019; 21.6\% have dried up in areas without vegetation, and $24.7 \%$ have classified as agricultural use. When analyzing the change of agricultural land, most of it has mainly gone to areas without vegetation and forests, with $31.1 \%$ and $24.6 \%$, respectively. $41.2 \%$ of meadows and thickets have changed to agricultural land, while $24 \%$ have given rise to soils without vegetation. Forest areas have mostly changed to soils without vegetation and agricultural land, with $28.5 \%$ and $21.7 \%$, respectively. Otherwise, the categories with the highest percentages of soil cover maintenance, that is, that did not change over time were snow, soils without vegetation, forests, and agriculture with $46.7 \%, 40.3 \%, 33.3 \%$, and $30.1 \%$ respectively.

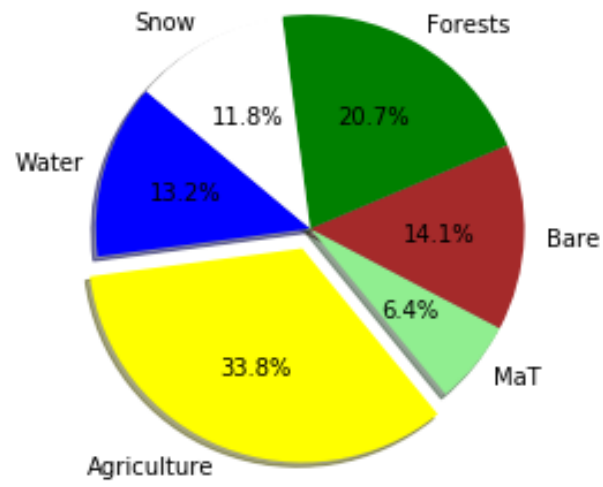

(a)

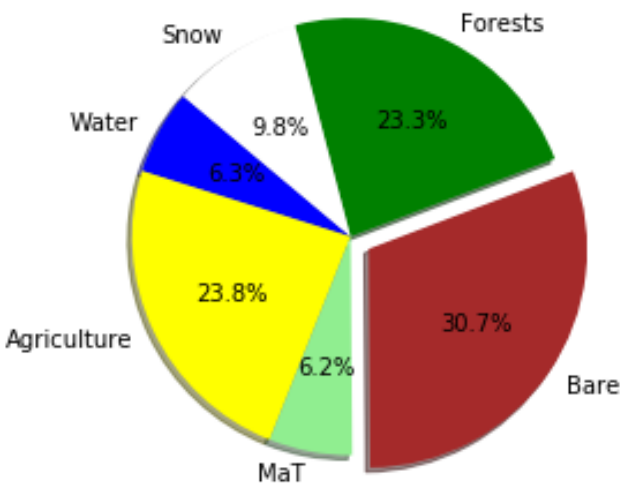

(b)

Figure 4. LULC percentage of the class change between (a) 1999 and (b) 2019. The highest percentage is highlighted.

\begin{tabular}{|l|c|c|c|c|c|c|}
\hline LULC & Water & Agriculture & MaT & Bare & Forest & Snow \\
\hline Water & 11.6 & 24.7 & 6.1 & 21.6 & 32.0 & 1.0 \\
Agriculture & 4.1 & 30.1 & 7.2 & 31.1 & 24.6 & 2.7 \\
MaT & 4.9 & 41.2 & 11.8 & 24.0 & 15.8 & 1.9 \\
Bare & 6.0 & 19.6 & 6.3 & 40.3 & 10.5 & 16.0 \\
Forest & 7.8 & 21.7 & 4.6 & 28.5 & 33.3 & 3.6 \\
Snow & 4.1 & 2.4 & 2.4 & 33.6 & 10.1 & 46.7 \\
\hline
\end{tabular}

Table 1. Changes in LULC in percentage (\%), specifying each type of change.

According to the total changes in land cover (Table 2), an alarming figure of $24.7 \%$ change from land to cover without vegetation can be seen, is the most considerable change recorded, followed by forests and agriculture. This is consistent with the growth of $16.3 \%$ of areas without vegetation presented in Figure 5. Forests and agricultural soils take second and third place with $16.2 \%$ and $13.4 \%$ respectively. 


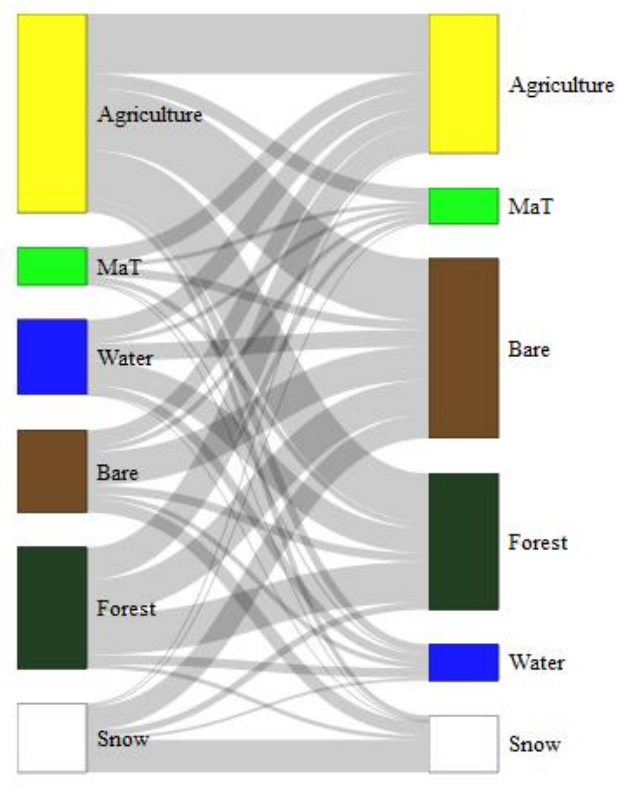

Figure 5. Sankey diagram for the specific LULC change. The left column is for the year 1999, while the right column corresponds to 2019 .

\begin{tabular}{|l|c|c|}
\hline LULC & Total class change & Class maintenance \\
\hline Water & $4.6 \%$ & $1.5 \%$ \\
Agriculture & $13.4 \%$ & $10.2 \%$ \\
MaT & $5.3 \%$ & $0.8 \%$ \\
Bare & $24.7 \%$ & $5.7 \%$ \\
Forest & $16.2 \%$ & $6.9 \%$ \\
Snow & $4.2 \%$ & $5.5 \%$ \\
\hline
\end{tabular}

Table 2. Change and maintenance of LULC compared to the total quantity of pixels. Example: $4.6 \%$ of other classes of LULC became water bodies, while $1.5 \%$ have maintained in the original class.

\section{CONCLUSIONS}

When comparing both images, a large amount of agriculture is concentrated in the western sector of the basin in the year 2019. If analyzed for 1999, a more heterogeneous soil is observed, where the composition is diverse throughout the sub-basin. On the other hand, in 2019, the types of land cover are segregated and grouped with the same class.

At first glance, it can be deduced that the results indicate a decrease in bodies of water, vegetation, whether agricultural or natural. These results could be directly associated with the drought facing Chile and especially the Maule Region. Among the possible causes of this event, we can mention the increase of hydroelectric plants in the Maule River between the years of study, as well as the urban growth of nearby towns, in addition to the agricultural activity in the Region that corresponds mainly to agricultural and forestry monocultures (Salas et al., 2016). This could initiate new studies oriented to the impact of each activity mentioned above on the phenomena detected.

\section{ACKNOWLEDGEMENTS}

The authors thanks the Escuela de Ingeniería Civil and the Facultad de Ciencias de la Ingeniería of the Universidad
Católica del Maule for financial support to participate in the event.

\section{REFERENCES}

Alvenäs, G., Jansson, P.-E., 1997. Model for evaporation, moisture and temperature of bare soil: calibration and sensitivity analysis. Agric. For. Meteorol. 88, 47-56. https://doi.org/10.1016/S0168-1923(97)00052-X

Aronson, J., Del Pozo, A., Ovalle, C., Avendaño, J., Lavin, A., Etienne, M., 1998. Land Use Changes and Conflicts in Central Chile. Springer, Berlin, Heidelberg, pp. 155-168. https://doi.org/10.1007/978-3-662-03543-6_9

BCN, 2017. Hidrografía Región del Maule [WWW Document]. Bibl. del Congr. Nac. Chile. URL https://www.ben.cl/siit/nuestropais/region7/hidrografia.ht $\mathrm{m}$

Capucim, M.N., Brand, V.S., Machado, C.B., Martins, L.D., Allasia, D.G., Homann, C.T., de Freitas, E.D., Da Silva Dias, M.A.F., Andrade, M.F., Martins, J.A., 2015. South America Land Use and Land Cover Assessment and Preliminary Analysis of Their Impacts on Regional Atmospheric Modeling Studies. IEEE J. Sel. Top. Appl. Earth Obs. Remote Sens. 8, 1185-1198. https://doi.org/10.1109/JSTARS.2014.2363368

Congalton, R., Gu, J., Yadav, K., Thenkabail, P., Ozdogan, M., 2014. Global Land Cover Mapping: A Review and Uncertainty Analysis. Remote Sens. 6, 12070-12093. https://doi.org/10.3390/rs61212070

Congalton, R.G., 1991. A review of assessing the accuracy of classifications of remotely sensed data. Remote Sens. Environ. 37, 35-46. https://doi.org/10.1016/00344257(91)90048-B

Csiszár, C., Csonka, B., Földes, D., Wirth, E., Lovas, T., 2019. Urban public charging station locating method for electric vehicles based on land use approach. J. Transp. Geogr. 74, 173-180. https://doi.org/10.1016/J.JTRANGEO.2018.11.016

Curtis, C.A., Pasquarella, V.J., Bradley, B.A., 2019. Landscape characteristics of non-native pine plantations and invasions in Southern Chile. Austral Ecol. 44, 12131224. https://doi.org/10.1111/aec.12799

Echeverria, C., Coomes, D., Salas, J., Rey-Benayas, J.M., Lara, A., Newton, A., 2006. Rapid deforestation and fragmentation of Chilean Temperate Forests. Biol. Conserv. 130, 481-494. https://doi.org/10.1016/J.BIOCON.2006.01.017

Fan, X., Ma, Z., Yang, Q., Han, Y., Mahmood, R., 2014. Land use/land cover changes and regional climate over the Loess Plateau during 2001-2009. Part II: interrelationship from observations. Clim. Change 1-15. https://doi.org/10.1007/s10584-014-1068-5

Fierro, P., Quilodrán, L., Bertrán, C., Arismendi, I., Tapia, J., Peña-Cortés, F., Hauenstein, E., Arriagada, R., Fernández, E., Vargas-Chacoff, L., 2016. Rainbow Trout diets and macroinvertebrates assemblages responses from watersheds dominated by native and exotic plantations. Ecol. Indic. 60, 655-667. https://doi.org/10.1016/J.ECOLIND.2015.08.018

Garreaud, R.D., Boisier, J.P., Rondanelli, R., Montecinos, A., Sepúlveda, H., Veloso-Äguila, D., 2019. The Central Chile Mega Drought (2010-2018): A Climate dynamics perspective. Int. J. Climatol. joc.6219. https://doi.org/10.1002/joc.6219

GDC, 2017. Energía hidroeléctrica [WWW Document]. Gener. Chile. URL http://generadoras.cl/tipos-energia/energia- 
hidroelectrica

Gomez-Dans, J., 2020. Landsat DN to Radiance Script using GDAL and Numpy [WWW Document]. URL https://gist.github.com/jgomezdans/5488682 (accessed 1.25.20).

Grekousis, G., Mountrakis, G., Kavouras, M., 2015. An overview of 21 global and 43 regional land-cover mapping products. Int. J. Remote Sens. 36, 5309-5335. https://doi.org/10.1080/01431161.2015.1093195

Hansen, M.C., Potapov, P. V, Moore, R., Hancher, M., Turubanova, S.A., Tyukavina, A., Thau, D., Stehman, S. V, Goetz, S.J., Loveland, T.R., Kommareddy, A., Egorov, A., Chini, L., Justice, C.O., Townshend, J.R.G., 2013. High-resolution global maps of 21st-century forest cover change. Science 342, 850-3. https://doi.org/10.1126/science.1244693

Herold, M., Mayaux, P., Woodcock, C.E., Baccini, A. Schmullius, C., 2008. Some challenges in global land cover mapping: An assessment of agreement and accuracy in existing $1 \mathrm{~km}$ datasets. Remote Sens. Environ. 112, 2538-2556. https://doi.org/10.1016/J.RSE.2007.11.013

Ho, C.-F., Su, J., Tong, J., 2001. The Usage of GIS in Stormwater Management Master Plan, in: Bridging the Gap. American Society of Civil Engineers, Reston, VA, pp. 1-9. https://doi.org/10.1061/40569(2001)248

Huntra, P., Keener, T.C., 2017. Evaluating the Impact of Meteorological Factors on Water Demand in the Las Vegas Valley Using Time-Series Analysis: 1990-2014. ISPRS Int. J. Geo-Information 6, 249. https://doi.org/10.3390/ijgi6080249

IDE, 2017. Catastro de uso de suelo y vegetación [WWW Document]. CONAF. URL www.ide.cl/descarga/capas/item/catastros-de-uso-desuelo-y-vegetacion.html\%0D

Kalnay, E., Cai, M., 2003. Impact of urbanization and land-use change on climate. Nature 423, 528-532. https://doi.org/10.1038/nature01649.1.

Kar, S., Liou, Y.-A., 2019. Influence of Land Use and Land Cover Change on the Formation of Local Lightning. Remote Sens. 11, 407 https://doi.org/10.3390/rs11040407

Kruse, F.A., Lefkoff, A.B., Boardman, J.W., Heidebrecht, K.B., Shapiro, A.T., Barloon, P.J., Goetz, A.F.H., 1993. The spectral image processing system (SIPS) - interactive visualization and analysis of imaging spectrometer data. Remote Sens. Environ. 44, 145-163. https://doi.org/10.1016/0034-4257(93)90013-N

Legesse, D., Vallet-Coulomb, C., Gasse, F., 2003. Hydrological response of a catchment to climate and land use changes in Tropical Africa: case study South Central Ethiopia. J. Hydrol. 275, 67-85. https://doi.org/10.1016/S00221694(03)00019-2

Leroux, L., Congedo, L., Bellón, B., Gaetano, R., Bégué, A., 2018. Land Cover Mapping Using Sentinel-2 Images and the Semi-Automatic Classification Plugin: A Northern Burkina Faso Case Study, in: QGIS and Applications in Agriculture and Forest. John Wiley \& Sons, Inc., Hoboken, NJ, USA, pp. 119-151. https://doi.org/10.1002/9781119457107.ch4

Li, K.Y., Coe, M.T., Ramankutty, N., Jong, R. De, 2007. Modeling the hydrological impact of land-use change in West Africa. J. Hydrol. 337, 258-268. https://doi.org/10.1016/J.JHYDROL.2007.01.038

Li, Y., Chang, J., Luo, L., Wang, Y., Guo, A., Ma, F., Fan, J., 2019. Spatiotemporal impacts of land use land cover changes on hydrology from the mechanism perspective using SWAT model with time-varying parameters. Hydrol. Res. 50, 244-261. https://doi.org/10.2166/nh.2018.006

Liu, W., Agusdinata, D.B., Myint, S.W., 2019. Spatiotemporal patterns of lithium mining and environmental degradation in the Atacama Salt Flat, Chile. Int. J. Appl. Earth Obs. Geoinf. 80, 145-156. https://doi.org/10.1016/J.JAG.2019.04.016

Loveland, T.R., Irons, J.R., 2016. Landsat 8: The plans, the reality, and the legacy. Remote Sens. Environ. 185, 1-6. https://doi.org/10.1016/J.RSE.2016.07.033

Manuschevich, D., Sarricolea, P., Galleguillos, M., 2019. Integrating socio-ecological dynamics into land use policy outcomes: A spatial scenario approach for native forest conservation in south-central Chile. Land use policy 84, 31-42. https://doi.org/10.1016/J.LANDUSEPOL.2019.01.042

Markoski, P.R., Rolim, S.B.A., 2012. Evaluation of aster images for characterization and mapping of amethyst mining residues, in: ISPRS Annals of the Photogrammetry, Remote Sensing and Spatial Information Sciences. Melbourne, pp. 153-158.

Martínez Martínez, Y., Goecke Coll, D., Aguayo, M., CasasLedón, Y., 2019. Effects of landcover changes on net primary production (NPP)-based exergy in south-central of Chile. Appl. Geogr. 113, 102101. https://doi.org/10.1016/J.APGEOG.2019.102101

MOP-DGA, 2008. Plan director para la gestión de los recursos hídricos Cuenca del Río Maule, Fase II: Actualización del modelo de operación del sistema y formulación del plan. Santiago.

MOP-DGA, 2003. Bases Plan director para la gestión de los recursos hídricos en la Cuenca del Río Maule, diagnóstico. Santiago.

Morais, M.V.B. de, Urbina Guerrero, V.V., Martins, L.D., Martins, J.A., 2017. Dynamical downscaling of future climate change scenarios in urban heat island and its neighborhood in a Brazilian subtropical area, in: The 2nd International Electronic Conference on Atmospheric Sciences (ECAS 2017). pp. 16-31.

Morais, M.V.B., Freitas, E.D., Marciotto, E.R., Urbina Guerrero, V.V., Martins, L.D., Martins, J.A., 2018. Implementation of observed sky-view factor in a mesoscale model for sensitivity studies of the urban meteorology. Sustain.

https://doi.org/10.3390/su10072183

Nahuelhual, L., Carmona, A., Lara, A., Echeverría, C., González, M.E., 2012. Land-cover change to forest plantations: Proximate causes and implications for the landscape in south-central Chile. Landsc. Urban Plan. 107 ,

$12-20$ https://doi.org/10.1016/J.LANDURBPLAN.2012.04.006

Newbold, T., Hudson, L.N., Hill, S.L.L., Contu, S., Lysenko, I., Senior, R.A., Börger, L., Bennett, D.J., Choimes, A., Collen, B., Day, J., De Palma, A., Díaz, S., EcheverriaLondoño, S., Edgar, M.J., Feldman, A., Garon, M., Harrison, M.L.K., Alhusseini, T., Ingram, D.J., Itescu, Y., Kattge, J., Kemp, V., Kirkpatrick, L., Kleyer, M., Correia, D.L.P., Martin, C.D., Meiri, S., Novosolov, M., Pan, Y., Phillips, H.R.P., Purves, D.W., Robinson, A., Simpson, J., Tuck, S.L., Weiher, E., White, H.J., Ewers, R.M., Mace, G.M., Scharlemann, J.P.W., Purvis, A., 2015. Global effects of land use on local terrestrial biodiversity. Nature 520, 45-50. https://doi.org/10.1038/nature14324 
ODEPA, 2018. Región del Maule: Información regional 2018. Santiago.

Pereira, P., 2019. Soil degradation, restoration and management in a global change context. Academic Press.

Pettorelli, N., Laurance, W.F., O’Brien, T.G., Wegmann, M., Nagendra, H., Turner, W., 2014. Satellite remote sensing for applied ecologists: opportunities and challenges. J. Appl. Ecol. 51, 839-848. https://doi.org/10.1111/13652664.12261@10.1111/(ISSN)1365-2664.MON_JPE

Pielke, R.A., Pitman, A., Niyogi, D., Mahmood, R., McAlpine, C., Hossain, F., Goldewijk, K.K., Nair, U., Betts, R., Fall, S., Reichstein, M., Kabat, P., de Noblet, N., 2011. Land use/land cover changes and climate: modeling analysis and observational evidence. Wiley Interdiscip. Rev. Clim. Chang. 2, 828-850. https://doi.org/10.1002/wcc.144

Rojas, C., Munizaga, J., Rojas, O., Martínez, C., Pino, J., 2019. Urban development versus wetland loss in a coastal Latin American city: Lessons for sustainable land use planning. Land use policy 80, 47-56. https://doi.org/10.1016/J.LANDUSEPOL.2018.09.036

Rudke, A.P., Fujita, T., Almeida, D.S. de, Eiras, M.M., Xavier, A.C.F., Rafee, S.A.A., Santos, E.B., Morais, M.V.B. de, Martins, L.D., Souza, R.V.A. de, Souza, R.A.F., Hallak, R., Freitas, E.D. de, Uvo, C.B., Martins, J.A., 2019. Land cover data of Upper Parana River Basin, South America, at high spatial resolution. Int. J. Appl. Earth Obs. Geoinf. 83, 101926. https://doi.org/10.1016/J.JAG.2019.101926

Salas, C., Donoso, P.J., Vargas, R., Arriagada, C.A., Pedraza, R., Soto, D.P., 2016. The Forest Sector in Chile: An Overview and Current Challenges. J. For. 114, 562-571. https://doi.org/10.5849/jof.14-062

Schulz, J.J., Cayuela, L., Echeverria, C., Salas, J., Rey Benayas, J.M., 2010. Monitoring land cover change of the dryland forest landscape of Central Chile (1975-2008). Appl. Geogr. 30, 436-447. https://doi.org/10.1016/J.APGEOG.2009.12.003

Solecki, W.D., Oliveri, C., 2004. Downscaling climate change scenarios in an urban land use change model. J. Environ. Manage. 72, 105-115. https://doi.org/10.1016/j.jenvman.2004.03.014

Wilson, C.O., Liang, B., Rose, S.J., 2019. Projecting future land use/land cover by integrating drivers and plan prescriptions: the case for watershed applications. GIScience Remote Sens. 56, 511-535. https://doi.org/10.1080/15481603.2018.1533158

Xiao, J., Shen, Y., Ge, J., Tateishi, R., Tang, C., Liang, Y., Huang, Z., 2006. Evaluating urban expansion and land use change in Shijiazhuang, China, by using GIS and remote sensing. Landsc. Urban Plan. 75, 69-80. https://doi.org/10.1016/J.LANDURBPLAN.2004.12.005

Yu, Le, Liang, L., Wang, J., Zhao, Y., Cheng, Q., Hu, L., Liu, S., Yu, Liang, Wang, X., Zhu, P., Li, Xueyan, Xu, Y., Li, C., Fu, W., Li, Xuecao, Li, W., Liu, C., Cong, N., Zhang, H., Sun, F., Bi, X., Xin, Q., Li, D., Yan, D., Zhu, Z., Goodchild, M.F., Gong, P., 2014. Meta-discoveries from a synthesis of satellite-based land-cover mapping research. Int. J. Remote Sens. 35, 4573-4588. https://doi.org/10.1080/01431161.2014.930206

Zhao, Y., Feng, D., Yu, L., Wang, X., Chen, Y., Bai, Y., Hernández, H.J., Galleguillos, M., Estades, C., Biging, G.S., Radke, J.D., Gong, P., 2016. Detailed dynamic land cover mapping of Chile: Accuracy improvement by integrating multi-temporal data. Remote Sens. Environ. 183 , $170-185$. https://doi.org/10.1016/J.RSE.2016.05.016 